\title{
Review
}

\section{Who speaks for nature? On the politics of science}

\author{
Laura Ephraim \\ Philadelphia: University of Pennsylvania Press, 2018, 189pp. \\ ISBN: 97-80812249811
}

Contemporary Political Theory (2019) 18, S32-S36. https://doi.org/10.1057/s41296018-0231-6; published online 3 July 2018

The natural sciences have a peculiar prominence in arguments about environmental issues, including climate change. Climatology, glaciology, field botany, conservation biology, and others possess seemingly unrivalled authority to frame public understandings of anthropogenic climate change. But where does that authority originate and how is it sustained and justified? Here, climate science and political theory can intersect.

Of course, most practicing scientists would vehemently reject any suggestion that natural science is or should be inherently 'political.' Rather, politics 'interferes' with, prevents, or otherwise 'contaminates' science, which is 'above' politics. Accordingly, good policy based on good science will be 'non-political.'

Laura Ephraim contests the conventional view. Science, she argues, is, or must be viewed as, an inherently political enterprise. Acknowledging this reality need not debunk the authority of science (p. 3), but rather strengthens it. Lay citizens and science do (and should) mutually support each other in a political way. This support, along with epistemological validity, generates the authority of science. To the question that entitles her book, 'Who speaks for nature?' Ephraim replies that scientists rightly do, yet their authority is established, sustained, eroded, and challenged-in part-by processes outside science proper. These processes are political. The familiar worry about the 'politicization of science' is, then, mistaken and misleading.

Ephraim's position is a welcome corrective to the 'linear' conception of science, i.e. 'science proposes, policy makers implement'. Although her contention that scientific practice can be strengthened through constructive relations with citizens and policy elites is not unique (Brown, 2009; Fischer, 2017; Moore, 2017), her focus on the problem of authority is distinctive and raises significant questions about the sources and justification for trust in science, and perhaps also for distrust of science.

(C) 2018 Macmillan Publishers Ltd., part of Springer Nature. 1470-8914 Contemporary Political Theory Vol. 18, S1, S32-S36 www.palgrave.com/journals 
Ephraim's book begins with a long introductory chapter in which she sets out her basic thesis and arguments. Then follows four chapters consisting of close textual analysis of four authors in reverse chronological order (Arendt, Vico, Descartes, Hobbes), where she finds precursors of her ideas. The book ends with a short epilogue where she draws lessons for the present.

One of the key theses of her book is that natural scientists can 'speak for nature' insofar as they engage in 'the politics of world-building'. By this she means 'the embodied practices through which scientists and citizens struggle with and against each other to engage the material reality of their environments and bodies and compose a common world from these heterogeneous elements' (p. 4). Authority is produced through these 'collective, affective encounters between human and nonhuman bodies' (p. 29). Ephraim develops a notion of 'common sense' supporting both science and politics, seeing in it a 'potent well of creativity and scientific authority's enabling condition of possibility' (p. 4). She not only wants to clarify the political constitution of scientific authority, but also to ask whether it can be reshaped for 'democratic and ecological ends' (p. 2). This will require a citizen body that is democratic, ecologically literate, and open to communication with scientists, or at least advocates of science. Notably, she avoids Bruno Latour's 'new materialism' because it muddies representation and cannot adequately handle the problem of authority.

Her four textual chapters are designed to show that each of the four authors mentioned above prefigures the idea of world-building politics. Her treatment of Arendt brings together Arendt's notions of 'earth' and 'world', stressing that Arendt acknowledged earthly habitat as a condition for worldly political action. Yet Ephraim contests Arendt's notion that natural science, by disrupting ordinary perceptions and appearances, opposes 'common sense', since it neglects citizens' role in producing scientific authority. Rather, for Ephraim, scientific work and common sense must be mutually supportive, even integrated, not only through 'common sense' in politics, but in scientific practice as well. Curiously, Ephraim does not explore Arendt's own conception of authority, perhaps because she finds it irrelevant.

Ephraim's chapter on Vico emphasizes his ideas that science is produced historically and that scientists' authority is based on the involvement of scientists in the practice of producing a common world. This practice occurs through rhetoricespecially metaphorical representations-in common sense. When this common world is lacking, science becomes separated from and even 'an enemy to politics' (p. 90). In her chapter on Descartes, Ephraim refutes his prevailing reputation as an advocate for authoritarian politics based on logical abstraction; rather, she portrays Descartes's thought as quasi-democratic through accepting myth as a means of communicating truth. This is perhaps the most far-fetched interpretation of the four, though it provides a corrective to the common notion that Descartes lacked any nuanced conception of the public's interaction with science.

(C) 2018 Macmillan Publishers Ltd., part of Springer Nature. 1470-8914 Contemporary Political Theory Vol. 18, S1, S32-S36 S33 
Ephraim's chapter on Hobbes, without representing him as democratic, includes him also among those who conceive of world-building practices among citizens and between laypersons and scientists generate authority relations. Hobbes' scientific politics are less linear and more political from the outset than they appear. Despite appearances, Hobbes does not really embody the linear image of a topdown imposition of science on a passive multitude. The Hobbesian covenant is a product of the creativity of the covenanters, whose popular support agreement authorizes the science as well as the practice of sovereignty. Hence science is 'always already' political. The covenant is a metaphorical exercise in worldbuilding politics, even if the covenanters' power is over when the sovereign is authorized. Here, unlike in her treatment of Arendt, Ephraim pays close attention to Hobbes' own notions of authority and representation in Chapter 16 of Leviathan to support her interpretation.

In an Epilogue of fewer than ten pages, Ephraim applies her conclusions about world-building politics to climate science. In summary: 'We must make science more, not less, political' (p. 143) by developing a public sphere in which the authority of climate science would be generated. Thus, Ephraim appears as an advocate of authority of science while also undermining the linear rhetoric normally used to try to defend that authority to an 'uninformed' lay public. 'Citizens, scientists, and sovereigns [sic!] must work together to revitalize a worldly politics of science' (p. 145). This imperative won't persuade those who see politics as 'contaminating' science and undermining public trust in science. But, as Ephraim states in a previous passage: '[The alternative would be] a science trained in the public school of politics, conversant in both vernacular and erudite languages, and sharp [sic] enough to recognize metaphorical connections forged in the past and to participate in creating new ones. Such a science would stand to contribute to the renewal of politics by fostering greater intimacy with the givens of nature' (p. 90).

What to make of this? Several problems emerge. One is that Ephraim never really defines 'authority', surely one of the most difficult and contested terms in the history of Western political thought. She says that scientific 'authority' is not only a product of validity or knowledge, but also of world-building. Here, Ephraim seems to think of 'authority' as if it really meant 'legitimacy' (in the Weberian sense). Yet surely the word contains normative aspects that can't be easily separated from descriptive or factual ones. 'Authority', then, not only can be 'established, maintained, and eroded' (p. 1), but also justified or resisted. Ephraim says that her work will provide guidance for those challenging authority claims, but how? Moreover, what about competing authority claims, such as those emanating from fundamentalist religion or free-market economics?

Yet Ephraim's argument is attractive for democratic theory because it seems to ground (legitimate) authority in democratic practice. Indeed, her formulation is reminiscent of a familiar Rousseauian paradox: why will citizens work so hard to 
produce authority relations that confirm their dependence? The Rousseauian answer is that citizens, as subjects, embrace authority insofar as it embodies the impersonal general will, dependence on which is freedom. It would be interesting to know whether Ephraim would accept the consequences of this position.

For Ephraim, feeling, not only rational calculation, does, or should, undergird public authority (the 'aesthetic turn'). What sorts of feelings or emotions? Her reading of Hobbes might have led her to consider the political importance of fear. For Hobbes, fear inspires the search for authority on the part of each person, resulting in a collective decision to construct political authority and its science even though no one is enthusiastic about this outcome. Might fear be an emotion that could drive the world-building politics and authority of climate science? And (departing from Hobbes), whose fear? Do everyone's fears count equally, or do the fears of the poor and vulnerable matter more? Who is included and excluded from the world-building politics that justify the authority of science?-a question implicating fundamental issues of justice.

The book is short on diagnosis compared with the space taken up by textual interpretation. It is unclear how readings of older texts, no matter how astute or engaging, can substitute for an independent justification of her argument. What is needed is a fuller diagnosis of 'worldly' authority relations in science and politics as well as general theorizing about epistemic and practical authority. (Seventeenthand eighteenth century 'science', was obviously a very different enterprise and set of institutions than the sciences today.) Although Ephraim provides some hints, she doesn't really show why legitimate, or illegitimate, scientific authority is today a serious public problem. She mentions the Flint, Michigan, water crisis, with its false assurances by 'experts', but doesn't develop implications. What are grounds by which one can and should discredit, and even resist, authority claims by experts today? (Moore 2017, pp. 80 ff.) This question is crucial if one wants to contest climate denialisms (some of which could claim world-building foundations of their own). Ephraim also might have said more about the institutions through which improved world-building practices could operate.

Despite these limitations and questions, Ephraim has produced a very worthwhile book. She takes authority seriously; her focus on the issues of authority in relations between science and politics is distinctive and useful. Her textual interpretation as well as her own argument are innovative and suggestive. The book deserves to be read by students of both science and politics, especially those who fear the calamity of unmitigated climate change.

\section{References}

Brown, M. B. (2009). Science in democracy: Expertise, institutions, and representation. Cambridge, MA: MIT Press.

두 2018 Macmillan Publishers Ltd., part of Springer Nature. 1470-8914 Contemporary Political Theory $\quad$ Vol. 18, S1, S32-S36 S35 
Fischer, F. (2017). Climate change and the democratic prospect: Participatory governance in sustainable communities. Oxford: Oxford University Press.

Moore, A. (2017). Critical elitism: Deliberation, democracy, and the problem of expertise. Cambridge: Cambridge University Press.

Harlan Wilson

Oberlin College, Oberlin, OH 44074, USA

hwilson@oberlin.edu 